\title{
FINANCIAL PERFORMANCE: THE ROLE OF GOOD CORPORATE GOVERNANCE (CASE STUDY IN THE MANUFACTURING COMPANIES OF BASIC AND CHEMICAL INDUSTRIAL SECTORS REGISTERED ON THE INDONESIA STOCK EXCHANGE 2016-2018)
}

\author{
Ari Susanti1) \\ Sri Lestari2) \\ 1) 2)Sekolah Tinggi Ilmu Ekonomi Surakarta, Jawa Tengah, Indonesia
}

\begin{abstract}
This study aims to examine the effect of implementing good corporate governance as measured by an independent board of commissioners, board of directors, and audit committee on financial performance measured using Return of Equity (ROE). This research uses quantitative research. The population in this study are manufacturing companies in the basic and chemical industry sectors that consistently publish financial reports on the Indonesia Stock Exchange from 2016 to 2018. Based on the purposive sampling method, a sample of 11 companies is obtained each year to obtain 33 observational data. The data in this study use warpPLS 6.0 software. The results of this study indicate that the independent board of commissioners, the board of directors affect the financial performance, while the audit committee has no effect on financial performance.
\end{abstract}

Keywords: Independent Board of Commissioners, Board of Directors, Audit Committee, and Financial Performance (ROE). 


\section{PRELIMINARY}

Companies in business development increasingly focus on issues of social content for the purpose of maximizing economic performance to achieve the benefits of shareholders and socially responsible for the interests of society as a whole. Competition that often occurs both social, economic and environmental issues requires the formulation of strategies of shareholders and board of directors to advance the company. The board of directors requires transparency, efficiency and accuracy in making decisions so as to ensure the sustainability of the company in the long term.

Corporate governance has 6 (six) principles in delivered by Arguden (2013), namely responsibility, accountability, consistency, transparency, effectiveness and fairness. Application of principles in the company then creates corporate governance that is able to create successful businesses in the face of global competition. The conclusion is that corporate governance plays an important role and is a key role for the company's success.

Governance includes the relationship between management, shareholders, the board of directors and parties interested in the company's activities. Other parties other than internal management are external management, namely an independent board. The independent board attracts attention because it has professional knowledge in company management.

This study has a variable board of commissioners, board of directors, audit committee and financial performance that uses ROE. The study was conducted using data on companies in the basic and chemical industry sectors listed on the Indonesia Stock Exchange in 2016 to 2018. The problem statement was to find out the influence of the independent board of directors, the board of directors, the influence of the audit committee on financial performance.

\section{LITERATURE REVIEW}

\section{Good Corporate Governance (GCG)}

According to Subramaniam and Susela (2011) Good Corporate Governance (GCG) is corporate governance. Corporate governance is a part of shareholders, the role of 
shareholders indirectly in corporate decision making. Good corporate governance, the directors will be responsible to the parties concerned and shareholders.

\section{Independent Board of Commissioners}

Research conducted by Susanti and Riharjo (2013) explains that an independent board of commissioners acts as an independent and has the same responsibilities as the board of commissioners, namely overseeing the activities and policies made by directors and providing advice to directors if needed. The independent board of commissioners also provides advice to the board of directors if necessary. The proportion of independent commissioners can be formulated as follows:

Independent Board of Commmissioners $=\frac{\text { Independent commissioner }}{\text { Board of Commissioners }}$

\section{Board of Directors}

The board of directors plays a very important role and is the key to the company's resources. The board of directors is a financial resource that makes socially responsible investments. Scott (2001) argues that the approach through institutional perspective theory.

The board of directors controls which depends on its characteristics. Characteristics include the function of the board of directors and their numbers. The board of directors is also included in the external council which will provide a balance between interests, supervision so that there is a balance between stakeholders and the delivery of information provided.

The board of directors can be measured using the formula:

Board of directors $=\sum$ member of the board of directors

\section{Audit Committee}

The audit committee is the person who oversees the company, with the audit committee expected to control and monitor the decisions made by the manager, is 
decisions that are impartial to the parties but are binding on all parties that have an interest in the company. The audit committee is required to act independently and is a bridge between external auditors and the company and a bridge between the supervisor function of the board of commissioners and internal auditors (Thesarani, 2016).

According to Rahmat M. \& Iskandar T, (2009) Audit committees have members who have financial literacy who are able to improve performance and are able to prevent financial difficulties faced by the company. The competence of audit committee members can improve company performance and will help and reduce financial problems. The expectation is that the audit committee will help the company improve its performance and avoid financial difficulties.

According to Adams M, (1997) An effective audit committee is able to improve financial performance with the results of credibility and objectivity. Characteristics of a good audit committee can positively improve financial performance.

The size of the audit committee can be calculated using the number of audit committees that can be formulated as follows:

Audit committee $=\sum$ audit committee

\section{Financial performance}

Several studies conducted in various countries one of which is a study conducted by Shao (2018) that there is a relationship between corporate governance and company performance in China in companies registered from 2001 to 2015. The results of the study explain that the structure of corporate governance is determined by company ownership, the supervisory board has a positive effect on company performance.

This research uses Return on Equity (ROE) which is a ratio that shows how much equity in obtaining net income.

ROE can be calculated using the formula:

$$
\mathrm{ROE}=\frac{\text { Net profit }}{\text { Equity }}
$$




\section{Framework for Thinking}

A good frame of mind will theoretically explain the relationship between variables to be studied. Variable is a value characteristic of people, objects or activities that have certain variations determined by researchers to be studied and drawn conclusions. Based on this the researchers used the variable independent commissioners, boards of directors, audit committees and CSR affect financial performance.

Hypothesis 1: Independent Board of Commissioners is thought to influence financial performance

Hypothesis 2: the board of directors is thought to influence financial performance

Hypothesis 3: the audit committee is thought to influence financial performance

\section{Figure 1. Framework for Thinking}

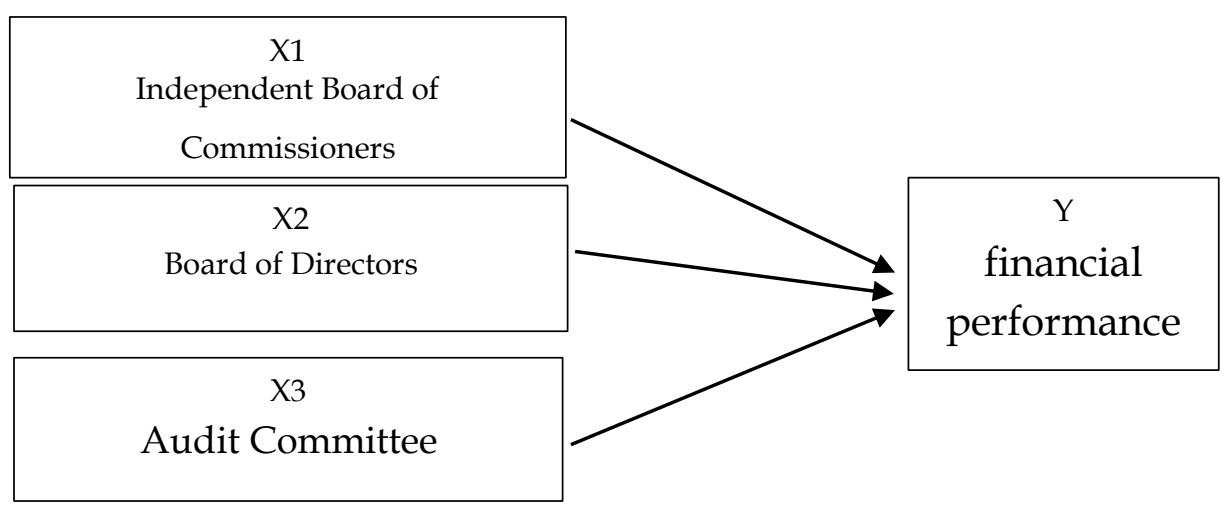

\section{RESEARCH METHODS}

The research conducted is quantitative research. The type of research data is secondary data. Secondary data used in this research is time series in the form of a list and company annual report data. Data analysis techniques are used to answer the problem formulation or to test hypotheses that have been formulated. Data management in this study uses warpPLS 6.0 software which is run on computer media.

Population and Sample

The population in this study are all basic industrial and chemical manufacturing companies listed on the Indonesia Stock Exchange in 2016, 2017 and 2018. Manufacturing 
companies in the basic industrial and chemical sectors are divided into 8 sectors totaling 71 companies listed therein.

The sampling method in this study uses a purposive sampling method, which is a non-random sampling technique where researchers determine the sampling sampel dengan how to determine specific characteristics that are in accordance with the objectives of the researcher and are expected to answer the research problem. Non random sampling is a sampling technique that does not provide equal opportunity for each member of the population to be used as a research sample. While special characteristics are made by researchers so that the sample can later meet the criteria that support and fit the research needs.

The criteria that make consideration in sampling in this study are as follows:

1. Basic and chemical industrial companies listed on the Indonesia Stock Exchange that have submitted Financial Statements and notes to the Financial Statements as of December 31 on a regular basis for three years in accordance with the required research periods of 2016, 2017 and 2018.

2. The company that submits its data in full with the information needed is an independent board of commissioners, a board of directors, an audit committee and corporate social responsibility.

3. Companies registered as companies that list conventional (non-Sharia) shares.

The above considerations were made in order to produce a sample that can represent the actual conditions. There are 71 companies which have a population of 11 companies that fit the research criteria to be sampled for the period of 2016 to 2018. Based on the data, the number of samples in this study were 33 consisting of 11 companies for 3 periods in 2016-2018. Data Collection Procedure

The data collection technique used in this research is to use the documentation study method by collecting the financial statement documents of each company that were sampled during the 2016 to 2018 period obtained through www.idx.co.id and www.sahamok.com. 


\section{RESULTS AND DISCUSSION}

\section{DATA ANALYSIS RESULTS}

1. Goodness of fit test

There are 5 testing indexes of goodness of fit, namely average path coefficient (APC), average R-Square (ARS), average adjusted R-square (AARS), average block VIT (AVIF), and average full collinearity (AFVIF). Here are the results of the output goodness of fit:

Tabel 1 Results of The Output Goodness of Fit

\begin{tabular}{|l|c|c|c|c|}
\hline & \multicolumn{1}{|l|}{ Indeks } & $\mathrm{p}$-value & Criteria & Description \\
\hline APC & 0,249 & 0,029 & $\mathrm{p}<0,05$ & good \\
\hline ARS & 0,344 & 0,007 & $\mathrm{p}<0,05$ & good \\
\hline AARS & 0,277 & 0,020 & $\mathrm{p}<0,05$ & good \\
\hline AVIF & 1,193 & & $\mathrm{I}<3,3$ & $\operatorname{good}$ \\
\hline AFVIF & 1,406 & & $\mathrm{I}<3,3$ & $\operatorname{good}$ \\
\hline
\end{tabular}

Source: Secondary data processed, 2020

The output results above explain that the APC has an index of 0.249 with a p-value of 0.029. ARS has an index of 0.344 with a p-value of 0.007 and AARS has an index of 0.277 with a p-value of 0.020 . The AVIF value has an index of 1.193 while the AFVIF value has an index of 1.406.

Based on the APC, ARS, and AARS values already meet the criteria with a p-value <0.05. Whereas AVIF and AFVIF have criteria below 3.3, which means they meet the criteria. The test results above can be concluded that the goodness of fit test was declared fit or feasible.Uji Hipotesis

Hypothesis testing is used to prove the truth with research or hypothesis. The significant level used in the study was 5\%. The following results are presented in the form of a research model: 
Figure 2. Data Analysis Results

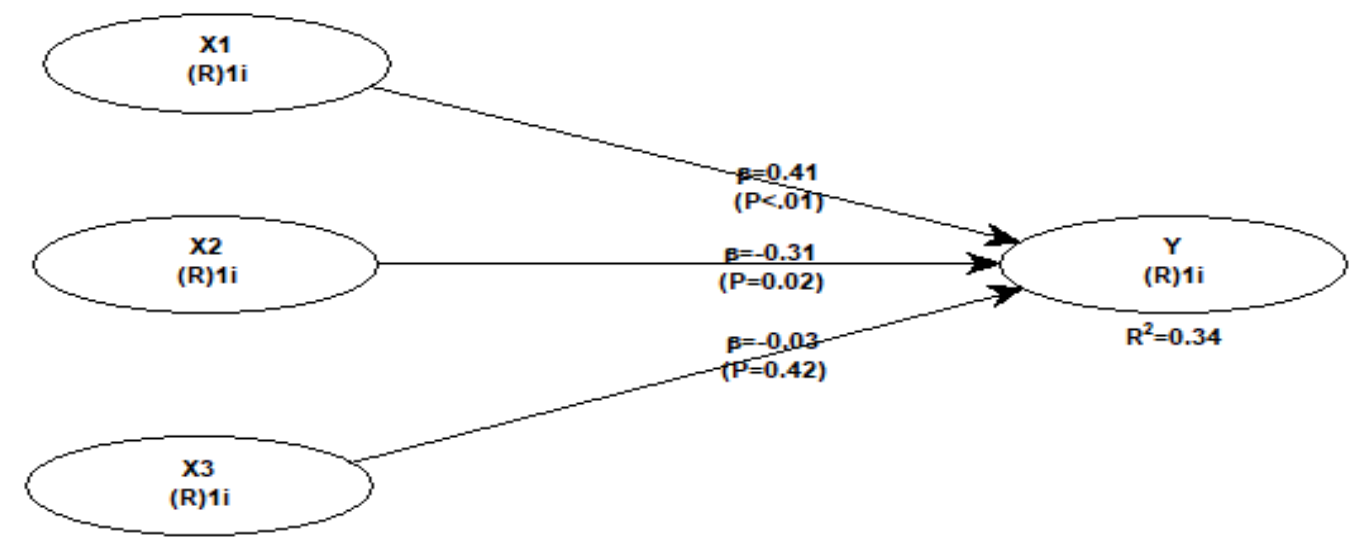

Lebih jelasnya hasil uji hipotesis disajikan dalam bentuk tabel berikut ini:

Tabel 2. Hasil Uji Hipotesis

\begin{tabular}{|l|c|c|c|c|}
\hline \multicolumn{1}{|c|}{ Kriteria } & Variabel & $\mathrm{X}_{1}$ & $\mathrm{X}_{2}$ & $\mathrm{X}_{3}$ \\
\hline Path & $\mathrm{X}_{1}$ & 0,41 & 0,31 & 0,035 \\
\hline coefficients & $\mathrm{X}_{2}$ & & \\
\hline $\mathrm{X}_{3}$ & $\mathrm{X}_{1}$ & 0,01 & 0,02 & 0,42 \\
$\mathrm{X}_{2}$ & $\mathrm{X}_{3}$ & & & \\
\hline $\begin{array}{l}\text { Effect size of } \\
\text { path }\end{array}$ & $\begin{array}{l}\mathrm{X}_{1} \\
\mathrm{X}_{2}\end{array}$ & 0,207 & 0,132 & 0,006 \\
\hline
\end{tabular}

Source: Secondary data processed, 2020

The output results above can be explained as follows:

1. H1: independent board of directors influences financial performance The independent commissioner variable has a positive and significant effect on financial performance as measured using ROE with a p-value of 0.01 $<0.05$. Beta coefficient value of 0.41 . This figure shows that if there is an increase in the assessment of the independent board of commissioners by one unit, the financial performance increases by 0.41 .

$\mathrm{R} 2$ value can be seen from the effect size with a value of 0.21 which means that the independent board of commissioners has an effect on financial 
performance measured using ROE of $20.7 \%$ and the rest is influenced by other variables.

2. H2: the board of directors influences financial performance

The board of directors variable has a positive and significant effect on financial performance as measured using ROE with a p-value of 0.02 $<0.05$. Beta coefficient value of 0.31 . This figure shows that if there is an increase in the assessment of the board of directors by one unit, financial performance increases by $0.31 \%$.

$R^{2}$ value can be seen from the effect size with a value of 0.132 which means that the board of directors influences the financial performance measured by ROE of $13.2 \%$ and the rest is influenced by other variables.

3. H3: audit committee influences financial performance

The audit committee variable has no influence on financial performance measured using ROE because the $p$-value is $0.42>0.05$. But the audit committee variable has a positive beta coefficient value of 0.03 which means that if there is an increase in the audit committee by one unit then the financial performance measured using ROE will increase by 0.03 and vice versa every time there is a decrease of one unit then the financial performance as measured using ROE will decrease by 0.03 .

$R^{2}$ value can be seen from the effect size with a value of 0.006 which means that the audit committee variable influences financial performance as measured using $\mathrm{ROE}$ of $0.06 \%$ and the rest is influenced by other variables.

\section{DISCUSSION}

This study aims to examine the influence of the independent board of commissioners, the board of directors and the audit committee to influence financial performance as measured using ROE in manufacturing companies in the basic and chemical sector sectors listed on the Indonesia Stock Exchange in 
2016-2018. Based on the analysis results, the discussion of research results is as follows:

1. The influence of the independent board of commissioners on financial performance

The results showed that the independent board of commissioners had a positive effect on financial performance measured using ROE. The existence of an independent board of commissioners would be able to influence the board of commissioners to be able to act independently in providing oversight to management so as to increase profits.

This study is in line with the research of Shanti Larasati (2017) which states that the proportion of independent commissioners has a positive effect on improving financial performance. This is because the independent board of commissioners truly carries out their duties and obligations, and is able to conduct supervision and provide input to directors in managing resources so that GCG can be applied.

\section{The influence of the board of directors on financial performance}

The results showed that the board of directors had a positive effect on financial performance as measured using ROE. The board of directors is needed in the company to carry out duties as a leader and is responsible for the running of the company. The board of directors has an obligation to formulate targets and carry out the company's strategy to achieve the company's goals.

This research is in line with Rahmawati Andhitya, et al. (2017). states that the number of influential board directors (ROE), this is explained by the number of boards of directors the more will make the coordination and operations of the company better, so as to improve company performance.

\section{The influence of the audit committee on financial performance}

The results showed that the audit committee had no effect on financial performance measured using ROE. But the audit committee 
variable has a positive influence on financial performance measured using ROE seen from the value of the path coefficient. Financial performance is not determined by the number of audit committees. The existence of the audit committee is only to comply with regulations and serve as a symbol that states that the company has implemented GCG.

This study is not in line with research conducted by Pakpaham, et al (2017) which states that the audit committee has a significant effect on financial performance. However, it is in agreement with Rahma Djazilah's (2016) research which states the audit committee that the audit committee has no effect on financial performance (ROE) because the audit committee works professionally and independently formed by the board of commissioners.

\section{CONCLUSION}

Based on the test results and the discussion that has been presented, the following conclusions can be drawn:

1. The independent commissioner variable has a significant effect on the financial performance variables measured using financial performance.

2. The variable of the board of directors has a significant effect on the financial performance variable measured using financial performance.

3. The audit committee variable does not have a significant effect on financial performance variables measured using financial performance..

\section{REFERENCE}

Adams M. (1997). Determinants of audit committee formation in the life insurance industry: New Zealand evidence. Journal of Business Research, 38(2); p. 123-129.

Argüden, Yilmaz. 2013. A Corporate Governance Model: Building Responsible Boards and Sustainable Business. Private Sector Opinion - Issue 17, A Global Corporate Governance Forum Publication.

Larasati, Shanti; Kartika Hendra Titisari dan Siti Nurlaela. (2017.) Pengaruh Good Corporate Governance dan Corporate Social Responsibility Terhadap Kinerja Keuangan Perusahaan Manufaktur Yang Terdaftar di BEI Seminar Nasional IENACO, ISSN: 2337-4349. 
Pakpahan, N; rasyid, E dan m, Hutajulu, F. (2017). Pengaruh Good Corporate Governance Terhadap Kinerja Keuangan. Fundamental Management Journal Online, eISSN: 2540-9220 Volume.2.

Rahmat M. \& Iskandar T. (2009). Audit committee characteristics in financially distressed and non-distressed companies. Managerial Auditing Journal, 24(7); 2009. p. 624-638.

Rahmawati Andhitya, Brady Rikumahu, dan Vaya Juliana Dillak. (2017). Pengaruh Dewan Direksi, Dewan Komisaris, Komite Audit Dan Corporate Social Responsibility Terhadap Kinerja Keuangan Perusahaan (Studi Kasus pada Perusahaan Sub Sektor Pertambangan Batu Bara yang terdaftar di Bursa Efek Indonesia Tahun 2013-2015) JURNAL AKUNTANSI \& EKONOMI FE. UN PGRI Kediri Vol. 2 No. 2, September 2017

Scott, W.R.,( 2001). Institutions and Organizations, 2nd ed. Sage, Thousand Oaks, CA

Shao, Lin, (2018). Dynamic Study of Corporate Governance Structure and Firm Performance in China: Evidence From 2001-2015. Chinese Management Studieshttps:// doi.org/10.1108/CMS-08-2017-0217.

Subramaniam, R., and Susela, D.S. (2011). Corporate governance and dividend policy in Malaysia. International Conference on Business and Economics Research, Kuala Lumpur, Malaysia, pp. 200-207.

Sugiyono. (2017). Metode Penelitian Kuantitatif, Kualitatif, dan RED. Bandung: Alfabeta

Susanti, Susi dan Ikhsan Budi Riharjo. (2013). Pengaruh Good Corporate Governance Terhadap Corporate Social Responsibility Pada Perusahaan Cosmetics And Household. Jurnal Ilmu dan Riset Akuntansi. Volume 1, Nomor 1. Hal 152 - 167.

Thesarani Juita Nurul. (2017). Pengaruh Ukuran dewan Komisaris, Kepemilikan Manajerial, Kepemilikan Institusional dan Komite Audit Terhadap Struktur Modal. Jurnal Nominal Volume VI Nomor 2 / Tahun 2017. 